\title{
THE ROLE OF HOMOCYSTEINE AND OTHER ENDOGENOUS INTOXICATION MARKERS IN THE PATHOGENESIS OF LICHEN PLANUS
}

\author{
Tetiana V. MELNYK ${ }^{1 凶}$, Sergiy A. BONDAR ${ }^{1}$ \\ ${ }^{1}$ Department of Skin and Venereal Diseases, National Pirogov Memorial Medical University, Vinnytsya, \\ Vinnytsia, Ukraine
}

Received 05 July 2019, Accepted 21 August 2019

hitps://doi.org/10.31688/ABMU.2019.54.3.16

\begin{abstract}
Introduction. Lichen planus (LP) is a chronic poly-etiologic dermatosis by the mechanism of its development, manifested by papular rash on the skin and mucous membranes, severe itching.

The objective of the study was to determine and analyze the levels of endogenous intoxication markers in blood plasma of the patients with lichen planus depending on severity and duration of the disease.

Materials and methods. 48 patients, 20 men and 28 women, participated in the study. 31 patients had suffered from dermatosis for about 2 years, and $17 \mathrm{pa}$ tients for over 2 years. Mild LP was diagnosed in 17 patients and moderate LP in 31 patients. The blood levels of homocysteine (HC), carbonyl groups of oxidative modified proteins (CG-OMP) and medium molecular weight peptides (MMWP) were determined in all the patients.
\end{abstract}

Results. Significantly increased blood plasma levels of HC, MMWP and CG were found in patients with lichen planus as compared to the control group. The patients with severe and prolonged course of dermatosis had more evident disturbances in the content

\section{Résumé}

Étude du rôle de l'homocystéine et d'autres marqueurs de l'intoxication endogène dans la pathogenèse du développement du lichen plan

Introduction. Le lichen plan (LP) est une dermatose poly-étiologique chronique selon son mécanisme d'apparition qui se manifeste par une éruption papuleuse sur la peau et les muqueuses, ainsi que par des démangeaisons intenses.

L'objectif de cette étude est d'identifier et d'analyser le niveau de marqueurs d'intoxication endogène dans le plasma sanguin de patients atteints de lichen plan selon la gravité et la durée de la maladie.

Matériaux et méthodes. Nous avons surveillé $48 \mathrm{pa}-$ tients atteints de LP: 20 hommes et 28 femmes. Chez 31 patients, la dermatose a duré moins de 2 ans, chez 17 patients - plus de 2 ans. Un faible degré de LP a été diagnostiqué chez 17 patients, un moyen - chez 31 . On a déterminé dans le sang de tous les patients les taux de l'homocystéine (Hcy), des carbonyles des protéines modifiées par oxydation (C-PMO) et des peptides d'un poids moléculaire moyen (PPMM). 
of endogenous intoxication markers than those with short and mild course of the disease.

Conclusions. A significant increase in the levels of homocysteine, MMWP and carbonyl groups of oxidative modified proteins was found in the patients with LP, being indicative of an essential role of endogenous intoxication processes in the pathogenesis of lichen planus.

Keywords: lichen planus, endogenous intoxication, homocysteine.

\section{List of abbreviations:}

$\mathrm{HC}$ - homocysteine

CG-OMP - carbonyl groups of oxidative modified proteins

MMWP - medium molecular weight peptides

\section{INTRODUCTION}

The yearly incidence of chronic dermatoses (psoriasis, eczema, lichen planus, atopic dermatitis etc.) is on the rise. Lichen planus is a chronic inflammatory disease, manifested by monomorphic papular rash on the skin and mucous membranes, characterized by mild to severe itching ${ }^{1-3}$. Classic lesions of LP are flat-topped, polygonal, violaceous papules and plaques with fine white lines called Wickham striae most commonly affecting the skin and oral mucosa ${ }^{4,5}$. Lichen planus (LP) is also characterized by frequent relapses, development of severe, torpid forms of the disease, affecting the patients' working capacity and quality of life ${ }^{6,7}$. The pathogenesis of this dermatosis is complicated and currently not clearly understood $^{8-10}$. Accordingly, numerous studies are conducted to identify the major links in its pathogenesis, including those devoted to the combined effect of hereditary, neuroendocrine, immune and metabolic factors ${ }^{11-14}$. A number of authors insist on the role of endogenous intoxication (EI), which is considered a nonspecific syndrome occurring due to increased tissue decomposition, insufficient processes of endogenous toxin inactivation ${ }^{15,16}$. Typically, this process is caused by several factors. The factors of secondary toxic auto-aggression, along with the factors of primary toxemia, play a key role in the development of endogenous intoxication syndrome. They are lysosomal enzymes, products of non-enzyme proteolysis, oligopeptides, included in the so-called medium weight molecules, and free radical oxidation products ${ }^{17-19}$.

Since the range of factors leading to endogenous intoxication in LP has not been fully determined yet, the indices of metabolic products and their role in the development of endo-toxicosis processes should
Résultats. Dans le plasma sanguin des patients atteints de LP, on a trouvé une augmentation significative du taux de Hcy, de PPMM et de C par rapport au groupe témoin. Chez les patients présentant une évolution plus sévère et prolongée des dermatoses, les modifications du contenu des marqueurs d'intoxication endogène étaient plus prononcées que chez les patients présentant une progression courte et légère.

Conclusions. Une augmentation significative du taux d'homocystéine, de PPMM et de carbonyles de protéines modifiées par oxydation a été observée chez les patients atteints de LP, ce qui indique un rôle significatif des processus d'intoxication endogène dans la pathogenèse de la LP.

Mots-clés: lichen plan, intoxication endogène, homocystéine.

be investigated ${ }^{20}$. Hence, publications on homocysteine and its role as endogenous toxin in the pathogenesis of chronic skin diseases warrant attention ${ }^{21,22}$. Homocysteine (HC) is a sulfur-containing amino acid with potential clinical significance ${ }^{23,24}$. Increased blood plasma $\mathrm{HC}$ content is caused by an imbalance between the production of amino acid methionine and its metabolism ${ }^{25}$. Since research on the role of homocysteine level in patients with LP is scarce in Ukraine, this has encouraged the authors to make it the subject of the present study.

The obJective of the Study was to determine the level of endogenous intoxication markers in blood plasma of the patients with lichen planus depending on the severity of the disease and its duration.

\section{Materials AND Methods}

48 patients with LP were studied - 20 men and 28 women, aged between 21 to 75 years. 31 patients had suffered from dermatosis for about 2 years, and 17 patients for over 2 years. All the patients were treated in the Dermatology Clinic (Vinnytsia, Ukraine), between 2016 and 2018. The study was based on the general principles and provisions of bioethics. In accordance with the Declaration of Helsinki on the Patients' Rights, all the patients were informed on the purpose of the study and methods of study procedures, followed by their written consent to participate in the study. Criteria for inclusion in the study were: diagnosis of lichen planus and consent to participate in the study. Exclusion criteria were the following: pregnancy and breast feeding, concomitant onco-pathology, acute infectious diseases, use of narcotic substances, refusal of the patient to participate in the study. 
The following endogenous intoxication parameters were determined in the blood plasma of patients with LP: homocysteine, medium molecular weight peptides and carbonyl groups of oxidative modified proteins,

The control group consisted of 32 apparently healthy individuals of similar age and sex, who came for preventive medical examinations.

Statistical analysis of study findings was performed using the program package STATISTICA 6.0. All data were presented as mean value $(\mathrm{M})$, and standard error of the mean $(\mathrm{M} \pm \mathrm{m}) . \mathrm{P}<0.05$ was considered to be significant difference.

\section{Results}

All the patients with LP were found to have an increased blood plasma level of homocysteine by 3.45 times $\left(\mathrm{P}_{1} \leq 0.001\right)$, carbonyl groups of oxidative modified proteins by 2.94 times $\left(\mathrm{P}_{1} \leq 0.001\right)$, MMWP by 1.8 times $\left(\mathrm{P}_{1}<0.001\right)$, as compared to the control group (Table 1).

Endo-toxicosis indices were analyzed depending on duration of dermatosis. Homocysteine level in the patients with dermatosis duration for more than 2 years was increased by 1.07 times $(12.3 \pm 0.3 \mu \mathrm{mol} / \mathrm{L})$ as compared to those who had suffered from the disease for 2 years or less $\left(11.42 \pm 0.1 \mu \mathrm{mol} / \mathrm{L}, \mathrm{P}_{2}<0.001\right)$.
The level of carbonyl groups in patients with dermatosis duration for more than 2 years was increased by 1.16 times $(3.35 \pm 0.2 \mathrm{nmol} / \mathrm{mg}$ of protein) as compared to those who had the disease for less than 2 years $\left(2.37 \pm 0.13 \mathrm{nmol} / \mathrm{mg}\right.$ of protein, $\left.\mathrm{P}_{2}<0.001\right)$. No significant difference was found in MMWP level of patients with dermatosis, irrespective of disease duration $-0.437 \pm 0.001 \mathrm{RU}$ versus $0.432 \pm 0.002 \mathrm{RU}$, $\mathrm{P}_{2}<0.05$. Thus, the levels of homocysteine and carbonyl groups of oxidative modified proteins are influenced by lichen planus duration to a greater extent than those of medium molecular weight peptides. Those results are presented in Table 2 .

Table 3 demonstrates the significant difference between endogenous intoxication indices in patients with different degrees of LP severity. The patients with moderate LP course proved to have higher levels of homocysteine, carbonyl groups and MMWP than those with mild lichen planus. Homocysteine level was $12.2 \pm 0.19 \mu \mathrm{mol} / \mathrm{L}$ in moderate LP, i.e. 1.12 times higher than in mild disease course $(10.89 \pm 0.3$ $\left.\mu \mathrm{mol} / \mathrm{L}, \mathrm{P}_{3}<0.001\right)$. The level of carbonyl groups of oxidative modified proteins appeared to be $3.24 \pm 0.17$ $\mathrm{nmol} / \mathrm{mg}$ in moderate LP, i.e. 1.15 times higher than that in mild disease manifestations $-2.8 \pm 0.1 \mathrm{nmol} /$ $\mathrm{mg}, \mathrm{P}_{3}<0.001$. MMWP level in moderate LP was $0.438 \pm 0.001 \mathrm{RU}$, i.e. 1.02 times higher than that in mild disease $\left(0.427 \pm 0.001 \mathrm{RU}, \mathrm{P}_{3}<0.001\right)$.

Table 1. Endotoxicosis indices in patients with LP $(M \pm m)$

\begin{tabular}{cccc}
\hline Marker & $\begin{array}{c}\text { Control group, } \\
\mathrm{N}=32\end{array}$ & $\begin{array}{c}\text { Patients with LP, } \\
\mathrm{N}=48\end{array}$ & $\mathrm{P}$ \\
\hline Homocysteine, $\mu \mathrm{mol} / \mathrm{L}$ & $3.40 \pm 0.425$ & $11.74 \pm 0.32$ & $\mathrm{P}_{1} \leq 0.001$ \\
\hline Carbonyl groups, $\mathrm{nmol} / \mathrm{mg}$ of protein & $1.05 \pm 0.06$ & $3.09 \pm 0.12$ & $\mathrm{P}_{1} \leq 0.001$ \\
\hline Medium molecular weight peptides, relative units $(\mathrm{RU})$ & $0.24 \pm 0.011$ & $0.434 \pm 0.002$ & $\mathrm{P}_{1}<0.001$ \\
\hline
\end{tabular}

Table 2. Endogenous intoxication indices depending on LP duration

\begin{tabular}{ccccc}
\hline Marker & $\begin{array}{c}\text { Control group, } \\
\mathrm{N}=32\end{array}$ & $\begin{array}{c}\text { Patients with LP, dura- } \\
\text { tion - 2 years, N=31 }\end{array}$ & $\begin{array}{c}\text { Patients with LP, dura- } \\
\text { tion - over 2 years, N=17 }\end{array}$ & $\mathrm{P}$ \\
\hline Homocysteine, $\mu \mathrm{mol} / \mathrm{L}$ & $3.40 \pm 0.425$ & $11.42 \pm 0.1$ & $12.3 \pm 0.3$ & $\mathrm{P}_{2}<0.001$ \\
\hline Carbonyl groups, nmol/mg of protein & $1.05 \pm 0.06$ & $2.9 \pm 0.1$ & $3.35 \pm 0.2$ & $\mathrm{P}_{2}<0.001$ \\
\hline $\begin{array}{c}\text { Medium molecular weight peptides, } \\
\text { relative units (RU) }\end{array}$ & $0.24 \pm 0.011$ & $0.432 \pm 0.002$ & $0.437 \pm 0.001$ & $\mathrm{P}_{2}<0.05$ \\
\hline
\end{tabular}

Table 3. Endogenous intoxication indices depending on LP severity

\begin{tabular}{ccccc}
\hline Marker & $\begin{array}{c}\text { Control group, } \\
\mathrm{N}=32\end{array}$ & $\begin{array}{c}\text { Mild disease, } \\
\mathrm{N}=17\end{array}$ & $\begin{array}{c}\text { Moderate disease, } \\
\mathrm{N}=31\end{array}$ & $\mathrm{P}$ \\
\hline Homocysteine, $\mu \mathrm{mol} / \mathrm{L}$ & $3.40 \pm 0.425$ & $10.89 \pm 0.3$ & $12.2 \pm 0.19$ & $\mathrm{P}_{3}<0.001$ \\
\hline Carbonyl groups, nmol/mg of protein & $1.05 \pm 0.06$ & $2.8 \pm 0.1$ & $3.24 \pm 0.17$ & $\mathrm{P}_{3}<0.001$ \\
\hline $\begin{array}{c}\text { Medium molecular weight peptides, relative } \\
\text { units (RU) }\end{array}$ & $0.24 \pm 0.011$ & $0.427 \pm 0.001$ & $0.438 \pm 0.001$ & $\mathrm{P}_{3}<0.001$ \\
\hline
\end{tabular}




\section{Discussion}

Several endo-toxicosis markers in peripheral blood of patients with LP were studied, and increased levels of homocysteine, carbonyl groups of oxidative modified proteins and MMWP were found. Increased homocysteine level is known to be a predictor of many pathological changes in the human body ${ }^{26,27}$. Observational studies consistently reported that elevated homocysteine is an independent risk factor for cardiovascular diseases. Several studies also consistently reported an association between psoriasis and increased cardiovascular risk. A substantial body of evidence also suggested that an elevated homocysteine level is related to the demethylation of DNA. Data from clinical trials also demonstrated that MTHFR C677T polymorphisms, as well as DNA methylation aberrations, are associated with psoriasi ${ }^{22,24,25}$. Its metabolism depends on cofactors, derivatives of vitamins ( $B_{6}, B_{11}$, folic acid). There is a significant association of deficiencies of iron, folic acid, and vitamin B12 and abnormally high blood homocysteine level with LP. There may be a close relationship between high blood homocysteine level and severity of $\mathrm{LP}^{21}$. In catabolism disturbances, the level of $\mathrm{HC}$ increases, leading to decreased production of heparinoids, activation of serine proteases, accumulation of lipid peroxidation products in the endothelium.

We did not find other research combining the study of the levels of homocysteine, MMWP and carbonyl groups of oxidative modified proteins in patients with LP. Homocysteine exerts a pronounced toxic effect on the body cells. Typically, hyperhomocysteinemia is associated with activation of peroxidation processes and oxidative modification of proteins, primarily plasma cell proteins. They are converted to secondary and tertiary structures, followed by their aggregation and fragmentation. To assess the intensity of protein peroxidation, the level of carbonyl groups should be determined ${ }^{16}$. Free radical oxidation of proteins results in oxidative DNA damage and modifications of gene transcription leading to mutations, synthesis of abnormal surface molecules, increased protein immunogenicity, and increased probability of autoantibody synthesis ${ }^{17,20}$. MMWPs are medium molecules, endogenous components with molecular weight 500-5000 Da. By molecular weight, they occupy an intermediate position between simple substances (urea, creatinine, bilirubin) and blood proteins. Increased MMWP levels lead to toxic effects on protein biosynthesis processes, suppressed phagocytic activity of leukocytes, proliferation of fibroblasts, the development of secondary immunosuppression ${ }^{18}$. Thus, the study findings, specifically significant increase in the levels of homocysteine, carbonyl groups of oxidative modified proteins, medium molecular weight peptides in patients with LP of various duration and severity, can be useful in the development of complex pathogenetic therapy of this dermatosis.

\section{Conclusions}

The study found increased levels of homocysteine, MMWP and carbonyl groups of oxidative modified proteins in patients with LP as compared to controls, as well as their direct proportional relationship with duration of the disease and its severity.

The major finding of the study is the evidence of the essential role of endogenous intoxication factors in the pathogenetic mechanisms of LP development. The study of these indicators can be useful for the clinical assessment of LP severity and for the effective treatment of this dermatosis.

\section{Compliance with Ethics Requirements:}

„The authors declare no conflict of interest regarding this article"

"The authors declare that all the procedures and experiments of this study respect the ethical standards in the Helsinki Declaration of 1975, as revised in 2008(5), as well as the national law. Informed consent was obtained from all the patients included in the study"

"No funding for this study"

\section{References}

1. Stepanenko VI (ed): Dermatology, Venerology. Textbook, (published in Ukrainian), Kyiv, KIM, 2013; 560.

2. Chaitanya NC, Chintada S, Kandi P, Kanikella S, Kammari A, Waghamare RS. Zinc therapy in treatment of symptomatic oral lichen planus. Indian Dermatology Online Journal. 2019;10(2):174-177.

3. Amraoui ME, Hassam B. Lichen with triple involvement: cutaneous, mucous and phanerian. The Pan African Medical Journal. 2018;31:12.

4. Aldana PC, Ramay FH, Steinweg SA, Driscoll MS. Lichen planus: five variants presenting in one patient. JAAD Case Reports. 2019;5(6):555-557.

5. Jose S, Mukundan JV, Johny J, Tom A, Mohan SP, Sreenivasan A. Estimation of serum cortisol levels in oral lichen planus patients with electrochemiluminescence. Journal of Pharmacy E B Bioallied Sciences. 2019;11(Suppl 2):265-268.

6. Zamani F, Haghighi M, Roshani M, Sohrabi M. Esophageal lichen planus stricture. Middle East Journal Digestive Diseases. 2019;11(1):52-54.

7. Ali AA, Basharat P, Lovegrove F. A dermatomyositis/lichen planus overlap syndrome presenting with erythroderma: A case report. SAGE Open Medical Case Reports. 2019;7: 2050313X19845174. https://www.ncbi.nlm.nih.gov/pmc/ articles/PMC6498764/ (Accessed on July 1, 2019).

8. Babu A, Chellaswamy S, Muthukumar S, Pandey B, Jayaraj M, Francis S. Bullous lichen planus: case report and review. 
Journal of Pharmacy and Bioallied Sciences. 2019;11(Suppl 2):499-506

9. Shimada K, Ochiai T, Hasegawa H. Ectopic transglutaminase 1 and 3 expression accelerating keratinization in oral lichen planus. Journal of International Medical Research. 2018;46(11):4722-4730

10. Humberto JSM, Pavanin JV, Rocha MJAD, Motta ACF. Cytokines, cortisol, and nitric oxide as salivary biomarkers in oral lichen planus: a systematic review. Brazilian Oral Research. 2018;32:e82. http://www.scielo.br/scielo. php?script=sci_arttext\&pid=S1806-83242018000100403\&1$\mathrm{ng}=\mathrm{en} \& \mathrm{nrm}=\mathrm{iso} \& \ln \mathrm{ln}=\mathrm{en}$ (Accessed on July 1, 2019).

11. Akram Z, Abduljabbar T, Vohra F, Javed F. Efficacy of low-level laser therapy compared to steroid therapy in the treatment of oral lichen planus: A systematic review. Journal of Oral Pathology $\mathcal{E}$ Medicine 2018;47(1):11-17.

12. Brodovska NB, Denysenko OI. A study of cytokine content in the blood serum of patients with lichen ruber planus. Arch Balk Med Union 2018;53(3):349-354.

13. Németh CG, Röcken C, Siebert R, Wiltfang J, Ammerpohl $\mathrm{O}$, Gassling V. Recurrent chromosomal and epigenetic alterations in oral squamous cell carcinoma and its putative premalignant condition oral lichen planus. PLoS One. 2019;14(4). https://www.ncbi.nlm.nih.gov/pmc/articles/ PMC6456184/ (Accessed on July 1, 2019).

14. Hashba H, Bifi J, Thyvalappil A, Sridharan R, Sreenivasan A, Mathew P. Prevalence of metabolic syndrome in patients with lichen planus: A cross-sectional study from a tertiary care center. Indian Dermatology Online Journal. 2018;9:304-8. https://www.ncbi.nlm.nih.gov/pmc/articles/PMC6137655/ (Accessed on July 1, 2019).

15. Mutafchieva MZ, Draganova-Filipova MN, Zagorchev PI, Tomov GT. Oral lichen planus - known and unknown: a review. Folia Medica 2018;60(4):528-535.

16. Karimov IZ, Los-Yatsenko NG, Odynets OA, et al. Changes in serum oxidative modified proteins and DNA leukocytes in acute enteric infections. Infectious Diseases 2004;3:44-48. (in Ukrainian)
17. Trinity JD, Broxterman RM, Richardson RS. Regulation of exercise blood flow: role of free radicals. Free Radical Biology and Medicine. 2016;98:90-102.

18. Addor FAS. Antioxidants in dermatology. Anais Brasileiros de Dermatologia. 2017;92(3): 356-362.

19. Schilling L, Vogt T. Lichen ruber planus. Der Hautarz 2018;69(2):100-108.

20. Xian D, Song J, Yang L, Xiong X, Lai R, Zhong J. Emerging roles of redox-mediated angiogenesis and oxidative stress in dermatoses. Oxidative Medicine and Cellular Longevity. 2019;2019:2304018. https://www.ncbi.nlm.nih.gov/pmc/ articles/PMC6501144/ (Accessed on July 1, 2019).

21. Chen HM, Wang YP, Chang JY, Wu YC, Cheng SJ, Sun A. Significant association of deficiencies of hemoglobin, iron, folic acid, and vitamin $B_{12}$ and high homocysteine level with oral lichen planus. Journal of the Formosan Medical Association 2015;114(2):124-129

22. Tobin A, Hughes R, Hand B, et al. Homocysteine status and cardiovascular risk factors in patients with psoriasis: a case-control study. Clinical and Experimental Dermatology 2011; 36(1):19-23.

23. Beranek M, Malkova A, Fiala Z, et al. Goeckerman therapy of psoriasis: genotoxicity, dietary micronutrients, homocysteine, and MTHFR gene polymorphisms. International Journal of Molecular Sciences. 2019;20(8):1908.

24. Wang WM, Jin HZ. Homocysteine: a potential common route for cardiovascular risk and DNA methylation in psoriasis. Chinese Medical Journal (Engl). 2017;130(16):1980-1986.

25. Chen Y, Zhao S, Wang Y, et al. Homocysteine reduces protein S-nitrosylation in endothelium. International Journal of Molecular Medicine 2014:34(5):1277-1285.

26. Diaconu C, Dumitru N, Fruntelata A, Lacau S, Bartos D. Apical hypertrophic cardiomyopathy: the ace-of-spades as the disease card. Acta Cardiologica Sinica 2015;31(1):1:83-86.

27. Diaconu CC, Arsene D, Paraschiv B, Balaceanu A, Bartos D. Hyponatremic encephalopathy as the initial sign of neuroendocrine small cell carcinoma - case report. Acta Endocrinologica. 2013;IX(4): 637-642. 